\title{
EFFECT OF ALTITUDE ON NUTRIENT CONCENTRATION, NUTRIENT STOCK AND UPTAKE IN FINE ROOT OF SAL (Shorea robusta Gaertn.) FOREST IN TERAI AND HILL AREAS OF EASTERN NEPAL
}

\author{
Krishna Prasad Bhattarai ${ }^{1 *}$, Tej Narayan Mandal ${ }^{2}$, Tilak Prasad Gautam ${ }^{3}$ \\ ${ }^{I}$ Department of Botany, Mechi Multiple Campus, Tribhuvan University, Bhadrapur, Nepal \\ ${ }^{2}$ Department of Botany, Post Graduate Campus, Tribhuvan University, Biratnagar, Nepal \\ ${ }^{3}$ Department of Botany, Mahendra Morang A. M. Campus, Tribhuvan University, Biratnagar, Nepal \\ "Corresponding author: krishnaprbhattarai@gmail.com
}

(Received: March 15, 2020; Revised: May 9, 2020; Accepted: May 14, 2020)

\begin{abstract}
The present study was conducted to understand the effect of altitude on the nutrient concentration, nutrient stock, and uptake in the fine root of the Terai Sal forest (TSF) and Hill Sal forest (HSF) in eastern Nepal. Annual mean fine root biomass in 0-30 cm soil depth was found higher in HSF $\left(6.27 \mathrm{Mg} \mathrm{ha}^{-1}\right)$ than TSF $\left(5.05 \mathrm{Mg} \mathrm{ha}^{-1}\right)$. Conversely, fine root production was higher in TSF $\left(4.8 \mathrm{Mg} \mathrm{ha}^{-1} \mathrm{y}^{-1}\right)$ than $\operatorname{HSF}\left(4.12 \mathrm{Mg} \mathrm{ha}^{-1} \mathrm{y}^{-1}\right)$. Nitrogen, phosphorus, and potassium content in fine roots were slightly higher in TSF than HSF. Nutrient concentration in fine roots of smaller size $(<2 \mathrm{~mm}$ diameter $)$ was nearly 1.2 times greater than that of larger size (2-5 mm diameter) in both forests. In HSF total stock of different nutrients $\left(\mathrm{kg} \mathrm{ha}^{-1}\right)$ in fine root was $55.62 \mathrm{~N}, 4.99 \mathrm{P}$, and $20.15 \mathrm{~K}$ whereas, these values were $49.49 \mathrm{~N}, 4.14 \mathrm{P}$, and $19.27 \mathrm{~K}$ only in TSF. However, total nutrient uptake $\left(\mathrm{kg} \mathrm{ha}^{-1} \mathrm{y}^{-1}\right)$ by fine root (both size classes) was greater in TSF (48.5 N, 4.3 P, and $18.6 \mathrm{~K})$ than $\mathrm{HSF}(36.9 \mathrm{~N}, 3.3 \mathrm{P}$, and $13.5 \mathrm{~K})$. The variability in fine root nutrient dynamics between these two forests was explained by the differences in fine root biomass and production which were influenced by the combined effect of varied altitude and season. The fine root, as being a greater source of organic matter, the information on its nutrient dynamics is inevitable for the management of soil nutrients in the forest ecosystem.
\end{abstract}

Keywords: Fine root biomass, Fine root production, Nitrogen, Phosphorus, Potassium

\section{INTRODUCTION}

Fine roots, the important below-ground nutrient source, are responsible for water and nutrient uptake and cycling (Gordon \& Jackson, 2000). The growth and development of fine roots are generally influenced by altitude, soil chemical properties, and other environmental parameters (Chang et al., 2012). Fine roots exert a significant influence between the outer environment and soil because they are the link between the above-ground carbon and soil carbon pool (Jackson et al., 1997). Fine root biomass changes continuously and productivity often exceeds above ground productivity although living fine root biomass constitutes only a small fraction of the total stand biomass (Helmisaari et al., 2002). So, carbon input into the soil through fine root litter may be several times larger than the corresponding inputs from the above ground litter (Scheffer \& Aerts, 2000) and contribute 25-80\% to the total soil carbon stock annually (Vogt et al., 1986). Fine root mortality is the important soil organic matter pool, and its rate represents the main factor of soil carbon and nitrogen cycling (Gill \& Jackson, 2000). Besides, fine root turnover contributes 18 to $58 \%$ of the total nitrogen of the forest nutrients (Vogt et al., 1986).

Despite its importance, studies on fine root dynamics are limited in the tropical forest ecosystem mainly due to difficulties in root sampling and controversies in determining the fine root biomass, although other aspects of the forest of Nepal were reported elsewhere (Bhujel et al., 2019; Bhandari et al., 2018; Rana et al., 2016). The study on nutrient concentration, nutrient stock, and uptake in fine root in Sal (Shorea robusta Gaertn.) forests located at different altitudes is new to Nepal. This study provides a basis for the comparison of nutrient dynamics in fine roots in the Sal forests located in varied altitudes in eastern Nepal. The information on fine root nutrients could be useful for the management of soil nutrients in the forest ecosystem, as it is a greater source of below-ground input of soil organic matter.

\section{MATERIALS AND METHODS}

\section{Study area}

The study was carried out in Sal forests located in the Terai and Hill regions of eastern Nepal, and they are addressed as Terai Sal forest (TSF) and Hill Sal forest (HSF) in this study. The TSF is located at Haldibari Rural Municipality-4 and 5, near the Jalthal village of the Jhapa district, Province 1 of eastern Nepal. The forest floor is uneven and altitudinal variation ranges from 62 to 129 masl (meter above sea level). It covers an area of 6300 ha and lies in between $87^{\circ} 55^{\prime}$ and $88^{\circ} 03^{\prime} \mathrm{E}$ and $26^{\circ} 26^{\prime}$ and $26^{\circ} 31^{\prime} \mathrm{N}$ (Fig. 1). Monthly minimum and maximum mean temperatures ranged between $17.3{ }^{\circ} \mathrm{C}$ and $30.6{ }^{\circ} \mathrm{C}$ and the average annual rainfall was $2734.3 \mathrm{~mm}$ in TSF. 
The HSF is located at Rong Rural Municipality-4, Kiteni near Kolbung village of Ilam district, Province 1of eastern Nepal. This forest covers an area of 3550 ha and lies at outer Himalaya (Siwaliks) having the altitudinal ranges from 500 to 850 masl. It is situated in between $88^{\circ} 02^{\prime}$ and $88^{\circ} 04^{\prime}$ E longitude and $26^{\circ} 44^{\prime}$ and $26^{\circ} 47^{\prime} \mathrm{N}$ latitude (Fig. 1). In HSF the mean monthly temperature range was $15.8{ }^{\circ} \mathrm{C}$ (minimum) to $22.2{ }^{\circ} \mathrm{C}$ (maximum) and the average annual rainfall was $1801.8 \mathrm{~mm}$. Climatic data of TSF was collected from Kankai Irrigation Base Camp Observatory, Gaida, Jhapa (90 masl), and for HSF it was collected from Ilam Base Camp Observatory, Ilam Bazar, Ilam (1200 masl) for the period 2001 to 2014, Department of Hydrology and Meteorology, Government of Nepal. Both TSF and HSF sampling sites are Sal (Shorea robusta Gaertn.) dominated mixed forests located along the altitudinal gradient in the moist tropical-subtropical regions. The climates of TSF and HSF are tropical and subtropical monsoon types, respectively.

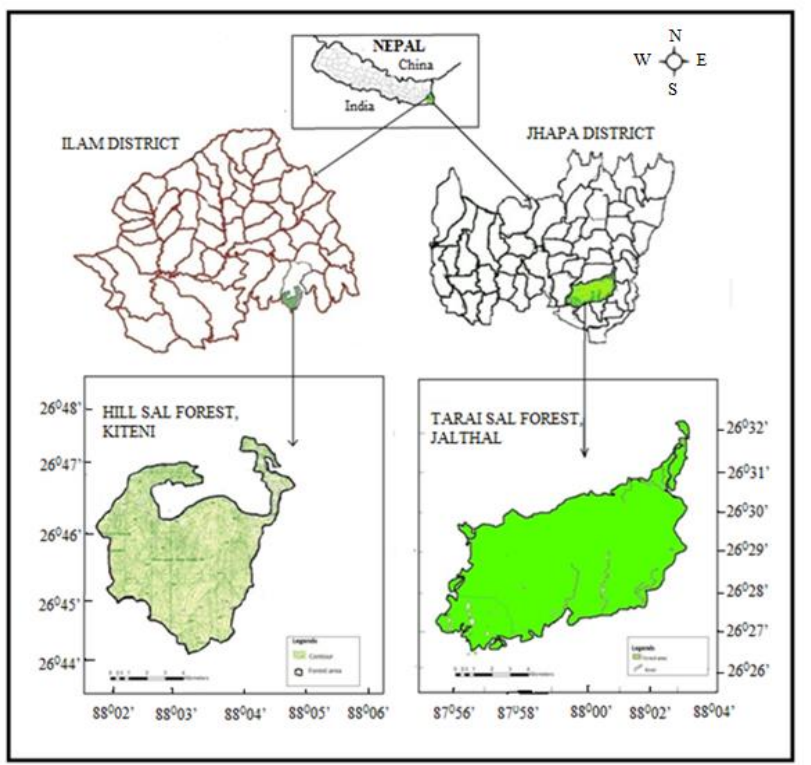

Fig. 1. Location map of the study area. (Source: Geographic Information Infrastructure Division, Survey Department, Government of Nepal)

Estimation of fine root biomass, production and turnover

Both forest stands of TSF and HSF were demarcated into the outer buffer area and inner core area. The inner core area considered as the sampling area was divided into 100 compartments. As per the partial random sampling, 30 compartments were selected randomly. Within each compartment, one $20 \mathrm{~m} \times 20 \mathrm{~m}$ permanent plot was fixed for the sampling of fine roots.

Fine root biomass was determined from 30 soil monoliths using $10 \mathrm{~cm} \times 10 \mathrm{~cm}$ pit size for two soil depth $0-15 \mathrm{~cm}$ and $15-30 \mathrm{~cm}$ in each forest stand. Soil monoliths were taken out from permanent plots during summer, rainy and winter season in 2012 and 2013. Soil monoliths were washed over a sieve with a fine jet of water to retrieve the fine roots which were oven-dried at $80{ }^{\circ} \mathrm{C}$. Fine root diameter size $<2 \mathrm{~mm}$ and $2-5 \mathrm{~mm}$ in $0-15 \mathrm{~cm}$ and $15-30$ $\mathrm{cm}$ soil depth were separated and estimated separately by converting the size of the pit into hectare value. Summer, rainy and winter season values were averaged to obtain a mean annual fine root biomass. Fine root production was estimated as the difference between the maximum and minimum fine root biomass values, and the fine root turnover was calculated as a ratio of its production and annual mean biomass (Srivastava et al., 1986).

\section{Chemical analysis of fine root}

Fine root samples were pooled together in proportion to their volume to represent the annual sample for each site. The oven-dried samples of the fine root were ground separately and passed through a $1 \mathrm{~mm}$ mesh screen. Three separate samples of various components were analyzed for each site. A chemical analysis was done at Ecology Research Laboratory, Department of Botany of Post Graduate Campus, Biratnagar, Nepal.

Potassium was determined at Nepal Environmental and Scientific Services (P) Ltd, Thapathali, Kathmandu, Nepal. Total nitrogen concentration was determined by the micro-Kjeldahl method (Peach \& Tracey, 1956). Fine root sample $(0.5 \mathrm{~g})$ was digested in $20 \mathrm{~mL}$ concentrated sulphuric acid, using catalyst mixture (10: 1: 0.1 , potassium sulfate: copper sulfate: selenium power) and then distillate the aliquot with $40 \%$ sodium hydroxide. The distillate was received in $2 \%$ boric acid with a mixed indicator and titrated with $0.02 \mathrm{~N}$ sulphuric acid. Using the method developed by Allen et al. (1974), about 200 mg oven-dried plant material was digested in $7 \mathrm{~mL}$ triacid mixture (5:1:1, nitric acid: sulphuric acid: perchloric acid), cooled and transferred on a hot plate till the material became pink and diluted to $100 \mathrm{~mL}$ by using triple distilled water. Using $5 \mathrm{~mL}$ aliquot, ammonium molybdate, and stannous chloride, the total $\mathrm{P}$ was determined by developing blue color and by using a spectrophotometer. Potassium was estimated by atomic absorption spectrophotometer.

\section{Estimation of nutrient stock, uptake and turnover rate in fine root}

Nutrient stock and nutrient uptake in fine root was estimated by multiplying the fine root biomass and fine root production respectively with respective nutrient concentrations (Garkoti, 2012). The turnover rate $(k)$ for each element of the fine root in the forest floor was calculated as $k=\mathrm{A} /(\mathrm{A}+\mathrm{F})$, (Jenny et al., 1949), where $A$ is the amount of nutrient added to the forest floor annually by fine root and $F$ is the nutrient content of the lowest value of standing crop of the fine root in the annual cycle. 
Effect of altitude on nutrient concentration, nutrient stock and uptake in fine root of Shorea robusta forest...

Turnover time $(t)$ is the reciprocal of the turnover rate $(k)$ and is expressed as $t=1 / k$.

\section{Statistical analysis}

Statistical tests were carried out in SPSS (IBM Statistics, ver. 20) packages. The data were checked for normality (Kolmogorov-Smirnov test) before statistical analysis. Two ways ANOVA was used to test the significant difference in the fine root biomass due to stand type (TSF and HSF), seasons, and size class.

\section{RESULTS}

\section{Fine root biomass and production}

Table 1. Annual fine root biomass $\left(\mathrm{Mg} \mathrm{ha}^{-1}\right)$ with seasonal variation in Terai Sal forest and Hill Sal forest of eastern $\operatorname{Nepal}(\mathbf{n}=30)$

\begin{tabular}{|c|c|c|c|c|c|c|}
\hline \multirow{3}{*}{ Sites/seasons } & \multicolumn{3}{|c|}{$0-15 \mathrm{~cm}$} & \multicolumn{3}{|c|}{$15-30 \mathrm{~cm}$} \\
\hline & \multicolumn{3}{|c|}{ Size class $(\mathrm{mm})$} & \multicolumn{3}{|c|}{ Size class $(\mathrm{mm})$} \\
\hline & $<2 \mathrm{~mm}$ & $2-5 \mathrm{~mm}$ & Total & $<2 \mathrm{~mm}$ & $2-5 \mathrm{~mm}$ & Total \\
\hline \multicolumn{7}{|l|}{ TSF } \\
\hline Summer & $1.29 \pm 0.11$ & $0.58 \pm 0.16$ & $1.87 \pm 0.24$ & $0.42 \pm 0.07$ & $0.51 \pm 0.2$ & $0.93 \pm 0.23$ \\
\hline Winter & $2.56 \pm 0.07$ & $0.72 \pm 0.07$ & $3.28 \pm 0.07$ & $0.94 \pm 0.05$ & $0.58 \pm 0.09$ & $1.52 \pm 0.1$ \\
\hline Rainy & $4.12 \pm 0.13$ & $1.24 \pm 0.07$ & $5.36 \pm 0.12$ & $1.21 \pm 0.06$ & $1.03 \pm 0.09$ & $2.24 \pm 0.11$ \\
\hline Average & $2.65 \pm 0.1$ & $0.84 \pm 0.1$ & $3.5 \pm 0.14$ & $0.85 \pm .06$ & $0.7 \pm 0.12$ & $1.55 \pm 0.14$ \\
\hline \multicolumn{7}{|l|}{ HSF } \\
\hline Summer & $2.34 \pm 0.14$ & $0.93 \pm 0.09$ & $3.27 \pm 0.19$ & $0.73 \pm 0.07$ & $0.46 \pm 0.1$ & $1.2 \pm 0.13$ \\
\hline Winter & $3.06 \pm 0.09$ & $1.24 \pm 0.06$ & $4.3 \pm 0.1$ & $1.1 \pm 0.06$ & $0.42 \pm 0.07$ & $1.52 \pm 0.08$ \\
\hline Rainy & $4.79 \pm 0.14$ & $1.59 \pm 0.08$ & $6.38 \pm 0.17$ & $1.45 \pm 0.08$ & $0.75 \pm 0.08$ & $2.21 \pm 0.12$ \\
\hline Average & $3.39 \pm 0.12$ & $1.25 \pm 0.07$ & $4.64 \pm 0.15$ & $1.09 \pm 0.15$ & $0.54 \pm 0.08$ & $1.63 \pm 0.11$ \\
\hline
\end{tabular}

Table 2. Result of ANOVA for forest stands, season, and size class effects on fine root biomass in TSF and HSF

\begin{tabular}{lccc}
\hline Source of variation & $\mathrm{df}$ & $\mathrm{F}$ & $\mathrm{p}$ \\
Forest stand & 1 & 53.84 & $\mathrm{P}<0.001$ \\
Season & 2 & 239.48 & $\mathrm{P}<0.001$ \\
Size & 1 & 774.57 & $\mathrm{P}<0.001$ \\
Forest $\times$ season & 1 & 1.77 & $\mathrm{P}<0.001$ \\
Forest $\times$ size & 1 & 19.55 & $\mathrm{P}<0.001$ \\
Season $\times$ size & 2 & 64.82 & $\mathrm{P}<0.001$ \\
Forest $\times$ season $\times$ size & 2 & 1.59 & $\mathrm{P}<0.001$ \\
\hline
\end{tabular}

Fine root production was significantly $(\mathrm{P}<0.001)$ higher (4.8 $\mathrm{Mg} \mathrm{ha}^{-1} \mathrm{y}^{-1}$ ) in TSF than HSF (4.12 $\mathrm{Mg} \mathrm{ha}^{-1} \mathrm{y}^{-1}$ ). It was $13 \%$ higher than the HSF. The production of fine root decreased significantly with the increase in root size class and soil depth (Table 3). Fine root production of $<2$ $\mathrm{mm}$ size class was higher by $75 \%$ and $77 \%$ than $2-5 \mathrm{~mm}$
The annual mean fine root biomass was higher in HSF (6.27 $\mathrm{Mg} \mathrm{ha}^{-1}$ ) than TSF (5.05 $\mathrm{Mg} \mathrm{ha}^{-1}$ ). The biomass of fine root in the $0-15 \mathrm{~cm}$ and $15-30 \mathrm{~cm}$ soil extensively varied among the stands and root-size class. In HSF biomass of $<2 \mathrm{~mm}$ size class fine root was $22 \%$ higher and 2-5 mm size class was $14 \%$ higher than TSF. With lower depth annual mean FRB was $69 \%$ in TSF and $74 \%$ in HSF in upper soil depth (Table 1). The maximum fine root biomass was recorded during the rainy season and minimum during the summer season (Table 1). ANOVA showed that the variation in fine root biomass was significantly $(\mathrm{P}<0.001)$ different for sites, season, and size (Table 2). size in TSF and HSF, respectively. In the upper soil depth, fine root production was found to be $3.48 \mathrm{Mg} \mathrm{ha}^{-1} \mathrm{y}^{-1}$ in TSF and $3.11 \mathrm{Mg} \mathrm{ha}^{-1} \mathrm{y}^{-1}$ in HSF. The turnover rate of the fine root in TSF was higher $(0.92 \mathrm{yr})$ than $\operatorname{HSF}(0.62 \mathrm{yr})$ for both size classes in the upper soil depth. Turnover rate was faster for $<2 \mathrm{~mm}$ size class than $2-5 \mathrm{~mm}$ in both the stands. Conversely, turnover time was longer in HSF (1.67yrs) than TSF (1.16 yrs) for both size classes.

The initial concentration of nitrogen, phosphorus, potassium, and carbon in the fine root $(<2 \mathrm{~mm}$ and $2-5$ $\mathrm{mm}$ ) of TSF and HSF are shown in Table 4. Nutrient concentration of fine roots varied widely with size and slightly with the site. Nitrogen, phosphorus, and potassium content in fine roots were slightly higher in TSF than HSF. Nitrogen concentration in fine root was highest, followed by potassium and phosphorus concentrations.

Nutrient concentration in fine root was nearly 1.2 times higher in $<2 \mathrm{~mm}$ diameter fine root than $2-5 \mathrm{~mm}$ diameter fine root in both forests. Percentage carbon in 
fine roots varied slightly with forests and root diameter. However, the Carbon: Nitrogen ratio of the fine root was higher in HSF than TSF in both size classes as determined by nitrogen concentration.

Table 3. Fine root production $\left(\mathrm{Mg} \mathrm{ha}^{-1} \mathbf{y}^{-1}\right)$ in Terai Sal forest (TSF) and Hill Sal forest (HSF) of eastern Nepal $(\mathrm{n}=30)$

\begin{tabular}{llccccc}
\hline \multirow{2}{*}{ Soil depth $(\mathrm{cm})$} & \multicolumn{3}{c}{ TSF } & \multicolumn{3}{c}{ HSF } \\
& $<2 \mathrm{~mm}$ & $2-5 \mathrm{~mm}$ & Total & $<2 \mathrm{~mm}$ & $2-5 \mathrm{~mm}$ & Total \\
\hline $0-15$ & $2.83 \pm 0.18$ & $0.65 \pm 0.07$ & $3.48 \pm 0.16$ & $2.45 \pm 0.02$ & $0.66 \pm 0.08$ & $3.11 \pm 0.24$ \\
$15-30$ & $0.79 \pm 0.07$ & $0.52 \pm 0.07$ & $1.31 \pm 0.09$ & $0.72 \pm 0.07$ & $0.28 \pm 0.05$ & $1 \pm 0.09$ \\
\hline Total & $\mathbf{3 . 6 2} \pm \mathbf{0 . 1 6}$ & $\mathbf{1 . 1 8} \pm \mathbf{0 . 0 8}$ & $\mathbf{4 . 8} \pm \mathbf{0 . 1 7}$ & $\mathbf{3 . 1 7} \pm \mathbf{0 . 0 6}$ & $\mathbf{0 . 9 5} \pm \mathbf{0 . 0 9}$ & $\mathbf{4 . 1 2} \pm \mathbf{0 . 2 1}$ \\
\hline
\end{tabular}

Table 4. Chemical concentration of fine root in Terai Sal forest (TSF) and Hill Sal forest (HSF) of eastern Nepal (\% \pm SE)

\begin{tabular}{|c|c|c|c|c|c|}
\hline Forests/size class & $\mathrm{N}$ & $\mathrm{P}$ & $\mathrm{K}$ & $\mathrm{C}$ & $\mathrm{C}: \mathrm{N}$ ratio \\
\hline \multicolumn{6}{|l|}{ TSF } \\
\hline$<2 \mathrm{~mm}$ & $1.04 \pm 0.03$ & $0.091 \pm 0.005$ & $0.41 \pm 0.01$ & $43 \pm 0.26$ & 42 \\
\hline $2-5 \mathrm{~mm}$ & $0.85 \pm 0.02$ & $0.077 \pm 0.004$ & $0.32 \pm 0.05$ & $44 \pm 0.3$ & 52 \\
\hline \multicolumn{6}{|l|}{ HSF } \\
\hline$<2 \mathrm{~mm}$ & $0.93 \pm 0.02$ & $0.083 \pm 0.002$ & $0.35 \pm 0.008$ & $44 \pm 0.3$ & 47 \\
\hline $2-5 \mathrm{~mm}$ & $0.78 \pm 0.04$ & $0.072 \pm 0.003$ & $0.25 \pm 0.009$ & $45 \pm 0.14$ & 58 \\
\hline
\end{tabular}

\section{Nutrient stock, uptake, and turnover in fine root}

Nutrient stock in fine root was higher in HSF than TSF. Variation in nutrient stock in fine roots is mainly accounted by the differences in the amount of FRB in the forest. In HSF total stock of different nutrients $\left(\mathrm{kg} \mathrm{ha}^{-1}\right)$ in fine root was $55.62 \mathrm{~N}, 4.99 \mathrm{P}$, and $20.15 \mathrm{~K}$ whereas, in TSF these values were $49.49 \mathrm{~N}, 4.14 \mathrm{P}$, and $19.27 \mathrm{~K}$ only. However, total nutrient uptake $\left(\mathrm{kg} \mathrm{ha}^{-1} \mathrm{y}^{-1}\right)$ by fine root (both size classes) was greater in TSF (48.5 N, 4.3 P, and 18.6 K) than HSF (36.9 N, 3.3 P, and 13.5 K) (Table 5).

Table 5. Nutrient stock $\left(\mathrm{kg} \mathrm{ha}^{-1}\right)$ and nutrient uptake (kg $h^{-1} y^{-1}$ ) in the fine root of Terai Sal forest (TSF) and Hill Sal forest (HSF) of eastern Nepal

\begin{tabular}{llllllll}
\hline Forest & \multicolumn{3}{l}{ Size } & \multicolumn{3}{c}{ Nutrient stock } & \multicolumn{3}{c}{ Nutrient uptake } \\
& $(\mathrm{mm})$ & $\mathrm{N}$ & $\mathrm{P}$ & $\mathrm{K}$ & $\mathrm{N}$ & $\mathrm{P}$ & $\mathrm{K}$ \\
\hline TSF & & & & & & & \\
& $<2$ & 36.4 & 3.2 & 14.3 & 37.5 & 3.3 & 14.8 \\
& $2-5$ & 13.1 & 1.0 & 4.9 & 11.0 & 0.9 & 3.8 \\
& Total & 49.5 & 4.1 & 19.3 & 48.5 & 4.3 & 18.6 \\
HSF & & & & & & & \\
& $<2$ & 41.7 & 3.7 & 15.7 & 29.5 & 2.6 & 11.1 \\
& $2-5$ & 14.0 & 1.3 & 4.5 & 7.4 & 0.7 & 2.4 \\
& Total & 55.6 & 5.0 & 20.2 & 36.9 & 3.3 & 13.5 \\
\hline
\end{tabular}

The turnover rate of fine root nutrients in TSF was higher than HSF for both size classes. Turnover rate of fine root nutrients of $<2 \mathrm{~mm}$ size $(\mathrm{N}=0.671$ and $0.593, \mathrm{P}=0.672$ and 0.594 and $K=0.671$ and 0.593 ) was higher than $2-5$
$\mathrm{mm}(\mathrm{N}=0.586$ and $0.563, \mathrm{P}=0.545$ and 0.561 and $\mathrm{K}=$ 0.585 and 0.562 ) in TSF and HSF respectively (Table 6). On the other hand, the turnover time of fine root nutrients was longer in HSF than TSF for both size classes.

\section{DISCUSSION}

Fine root biomass was higher in HSF than TSF which may be due to variation in altitude. High altitude influences the environmental condition due to alteration in air temperature, atmospheric humidity, rainfall, and soil moisture (Scowcroft et al., 2000). Hill Sal forest accumulates higher organic matter which may be due to a low turnover rate of fine root and leaf litter (Bhattarai \& Mandal, 2015; 2016). This results in a higher organic form of nitrogen which could be related to the high value of fine root biomass (Nasholm et al., 2009). As only a little information is available from Nepal, a comparable account of fine root biomass $\left(6.6 \mathrm{t} \mathrm{ha}^{-1}\right)$ and production (5.2 $\left.\mathrm{t} \mathrm{ha}^{-1} \mathrm{y}^{-1}\right)$ values were reported in Tropical Moist Forest of Sunsari district, eastern Nepal (Gautam \& Mandal, 2016).

However, total belowground tree root biomass $\left(36 \mathrm{t} \mathrm{ha}^{-1}\right)$, obviously quite a high value was reported in landslide affected area of Jure village (841 masl) in Sindhupalchowk district, Nepal (Acharya \& Khadka, 2016). Fine root production showed a higher value in TSF. The higher value of production may be due to the high rate of turnover. Girardin et al. (2013) explained a comparable finding of fine root production in tropical forests along an elevation gradient, ranging from the Peruvian Andes to lowland Amazonia. They recorded that fine root production decrease with an increase in altitude. 
Effect of altitude on nutrient concentration, nutrient stock and uptake in fine root of Shorea robusta forest...

A similar pattern of fine root production was also observed by Garkoti (2012) in high elevation Maple, Birch, and Rhododendron forests of Indian Central Himalaya.

Due to the variation in altitude the nutrient concentration (nitrogen, phosphorus, potassium) also varied in the fine root. Decreased nutrient concentration in the fine roots and other plant tissues in many tropical montane forests located at higher altitudes might be caused by increased nutrient immobilization in slowly decomposing humus

Table 6. Turnover rate (k) and turnover time (t) of fine root nutrients in Terai Sal and Hill Sal forest of eastern Nepal

\begin{tabular}{llllllll}
\hline Forest & Size $(\mathrm{mm})$ & \multicolumn{3}{c}{ Turnover rate $(\mathrm{k} / \mathrm{yr})$} & \multicolumn{4}{c}{ Turnover time (t, yr) } \\
& & $\mathrm{N}$ & $\mathrm{P}$ & $\mathrm{K}$ & $\mathrm{N}$ & $\mathrm{P}$ & $\mathrm{K}$ \\
\hline TSF & & & & & & & \\
& $<2$ & 0.671 & 0.672 & 0.671 & 1.49 & 1.48 & 1.49 \\
& $2-5$ & 0.586 & 0.545 & 0.585 & 1.71 & 1.83 & 1.7 \\
\hline HSF & & & & & & & \\
& $<2$ & 0.593 & 0.594 & 0.593 & 1.68 & 1.82 & 1.69 \\
& $2-5$ & 0.563 & 0.561 & 0.562 & 1.77 & 1.78 & 1.77 \\
\hline
\end{tabular}

Higher nutrient stock in the fine root of HSF is mainly due to the higher amount of fine root biomass rather than its nutrient concentration. In the TSF nutrient stock is less due to low fine root biomass even though its nutrient concentration is high. The amount of nutrients in fine root might also be the result of numerous external factors such as soil nutrients and climate besides internal factors. Helmisaari (2007) found a positive relationship between soil nitrogen and the amount of nitrogen in fine root in the European forests which showed similarity with the present work. Ibrahima et al. (2010) also found a lower nutrient amount in Ebimimbang located in lower altitude than Nyangong of the tropical rainforests.

Likewise, total nitrogen storage by fine root showed an increasing trend in the forest of the Changbai Mountains (Yangi et al., 2010). In the present study, fine root nutrient uptake was higher in TSF which was because of higher fine root production. A comparable amount of nutrient uptake was reported by Gautam and Mandal (2018) in Sal forest located at the Bhabar belt of Sunsari district in eastern Nepal. Garkoti (2012) also found that fine root nutrient uptake was higher in the Cappadocian maple forest located in lower altitude than in Himalayan birch and bell rhododendron forests. This result may be due to a decline in temperature at higher elevations in which plants divert large amounts of nutrients to underground parts.

\section{CONCLUSION}

The fine root biomass in HSF was higher than TSF. However, fine root production was higher in TSF. Nutrient stock in the fine root which was higher in HSF is mainly due to the higher amount of fine root biomass. The material (Tanner et al., 1998). Graefe et al. (2010) found that the nitrogen, phosphorus, and potassium concentration in fine root decrease with increasing altitude in three tropical mountain forest stands located in the eastern cordillera of the South Ecuadorian Andes. The thinner fine root contains a higher nutrient concentration than a thicker fine root. Similar trends between diameter and nutrient content in fine roots were also reported by Gordon and Jackson (2000).

nutrient uptake was higher in TSF which is because of higher fine root production. Thus, the differences in nutrient dynamics in the fine root of these two forests were explained by varied due to variation in the fine root biomass and production which were influenced by the combined effect of varied altitudes and seasons. The information on fine root nutrient dynamics could be a guideline for the management of soil nutrients in the forest ecosystem.

\section{ACKNOWLEDGEMENTS}

The authors are grateful to the University Grants Commission (UGC), Nepal for financial support. The first author was awarded Ph. D. research fellowship in 2011 AD from the UGC, Nepal.

\section{REFERENCES}

Acharya, S., \& Khadka, U. (2016). Loss of tree biomass in Jure landslide, Sindhupalchowk, Nepal. Journal of Institute of Science and Technology, 21(1), 65-70.

Allen, S. E., Grimshaw, H. M., Parkinson, J. A., \& Quarmby, C. (1974). Chemical analysis of ecological materials. Oxford, UK: Blackwell Scientific Publication.

Bhandari, A., Khadka, U., \& Kanel, K. (2018). Ecosystem services in the mid-hill forest of western Nepal: A case of Panchase protected forest. Journal of Institute of Science and Technology, 23(1), 10-17.

Bhattarai, K. P., \& Mandal, T. N. (2015). Fine root biomass and production in moist tropical Sal (Shorea robusta Gaertn.) bearing forest situated along 
topographic gradient in Eastern Nepal. Geobios, 42, 4-11.

Bhattarai, K. P., \& Mandal, T. N. (2016). Variation in litter mass and it's turnover in Tarai Sal forest and Hill Sal forest of eastern Nepal. Nepalese Journal of Biosciences, 6(1), 13- 18.

Bhujel, K., Byanju, R., \& Gautam, A. (2019). Wildlife dynamics and its effects on the forest resources and public property in Nepal. Journal of Institute of Science and Technology, 23(1), 61-68.

Chang, R., Fu, B., Yao, X., Liu, G., \& Wang, S. (2012). Effects of soil physicochemical properties and stand age on fine root biomass and vertical distribution of plantation forests in the Loess Plateau of China. Ecological Research, 27, 827-836.

Garkoti, S. C. (2012). Dynamics of fine root N, P, and K in high elevation forests of central Himalaya. Forest Studies in China, 14(2), 145-151.

Gautam, T. P., \& Mandal T. N. (2016). Fine root biomass and production in Tropical Moist Forest of eastern Nepal. International Journal of Ecology and Environmental sciences, 42(S), 29-41

Gautam, T. P., \& Mandal T. N. (2018). Storage and flux of nutrients in a disturbed and undisturbed tropical moist forest of Eastern Nepal. International Journal of Forestry Research, 12 pages. https://doi.org/10.1155/2018/8516321

Gill, R. A., \& Jackson, R. B. (2000). Global patterns of root turnover for terrestrial ecosystems. New Phytology, 147, 13-31.

Girardin, C. A. J., Aragão, L. E. O. C., Malhi, Y., Huasco, W. Huaraca, Metcalfe, D. B., Durand, L., Mamani, M., Silva-Espejo, J. E., \& Whittaker, R. J. (2013). Fine root dynamics along an elevational gradient in tropical Amazonian and Andean forests. Global Biogeochemical Cycles, 27, 252-264.

Gordon, W. S., \& Jackson, R. B. (2000). Nutrient concentration in fine roots. Ecology, 81(1), 275-280.

Graefe, S., Hertel, D., \& Leuschner, C. (2010). N, P, and $\mathrm{K}$ limitation of fine root growth along an elevation transect in tropical mountain forests. Acta Oecologica, 36, 537-542.

Helmisaari, H. L. (2007). Roots and carbon allocationquantity, quality, and controls. Rootrap session: belowground carbon turnover in European forests, Finish Forest Research Institute.

Helmisaari, H. S., Makkonen, K., Kellomaki, S., Valtonen, E., \& Malkonen, E. (2002). Below and aboveground biomass, production and nitrogen use in Scots pine stands in eastern Finland. Forest Ecology and Management, 165, 317-326.

Ibrahima, A., Mvondo, Z. A., \& Ntonga, J. C. (2010). Fine root production and distribution in the tropical rainforests of south-western Cameroon: effects of soil type and selective logging. Forest, 3, 130-136.

Jackson, R. B., Mooney, H. A., \& Schulze, E. D. (1997). A global budget for fine root biomass, surface area, and nutrient contents. Proceedings of the National Academy of Sciences, 94, 7362-7366.

Jenny, H., Gessel, S. P., \& Bingham, F. T. (1949). Comparative study of decomposition rates of organic matter in temperate and tropical regions. Soil Science, 68, 419-432.

Nasholm, T., Kielland, K., \& Ganeteg, U. (2009). Uptake of organic nitrogen by plants. New Phytologist, 182: $31-48$.

Peach, K., \& Tracey, M. V. (1956). Modern Methods of Plant Analysis. Vol. 1. Springer- Verlag, Berlin.

Rana, P., Koirala, M., Bhuju, D., \& Boonchird, C. (2016). Population structure of Rhododendron campanulatum D. Don and associated tree species along the elevational gradient of the Manaslu Conservation Area, Nepal. Journal of Institute of Science and Technology, 21(1), 95-102.

Scheffer, R. A., \& Aerts, R. (2000). Root decomposition and soil nutrient and carbon cycling in two temperate fen ecosystems. Oikos, 91, 541-549.

Scowcroft, P. G., Turner, D. R., \& Vitousek, P. M. (2000). Decomposition of Metrosideros polymorpha leaf litter along elevational gradients in Hawaii. Global Change Biology, 6, 73-85.

Srivastava, S. K., Singh, K. P., \& Upadhyay, R. S. (1986). Fine root growth dynamics in teak (Tectona grandis Linn. F). Canadian Journal of Forest Research, 16, 1360-1364.

Tanner, E. V. J., Vitousek, P. M., \& Cuevas, E. (1998). Experimental investigation of nutrient limitation of forest growth on wet tropical mountains. Ecology, $79,10-22$

Vogt, K. A., Grier, C. C., \& Vogt, D. J. (1986). Production, turnover and nutrient dynamics of above- and below ground detritus of world forests. Advances in Ecological Research, 15, 303-377.

Yangi, L., Wu, S., \& Zhang, L. (2010). Fine root biomass dynamics and carbon storage along a successional gradient in Changbai Mountains, China. Forestry, 83(4), 379-387. 